\title{
ADSORPTION-COUPLED REDUCTION OF HEXAVALENT CHROMIUM BY JUTE-BASED ANIONIC ADSORBENT FROM AQUEOUS SOLUTIONS
}

\author{
CANHUI DENG, ZEMAO YANG, ZHIGANG DAI, CHAOHUA CHENG, QING TANG, YING XU, CHAN \\ LIU, JIQUAN CHEN, DONGWEI XIE and JIANGUANG SU
}

\author{
Institute of Bast Fiber Crops, Chinese Academy of Agricultural Science, 348 West XianJiahu Road, \\ Changsha, 410082, PR China \\ $₫$ Corresponding author: S. Jianguang, jgsu@vip.163.com,dengcanhui@caas.cn
}

Received August 7, 2019

\begin{abstract}
A new efficient anion adsorbent was fabricated by amino-grafting lignocellulose-rich jute stalk (AGJ) to uptake toxic hexavalent chromium ( $\mathrm{Cr}(\mathrm{VI})$ ) from aqueous solutions. Batch adsorption experiments were performed as a function of adsorbent dosage and initial solution $\mathrm{pH}$ to test the adsorption-coupled reduction for anion $\mathrm{Cr}(\mathrm{VI})$. Maximum chromium adsorption was found at $\mathrm{pH} 2.0$ with an appropriate adsorbent dosage of $1.0 \mathrm{~g} / \mathrm{L}$. The adsorption equilibrium data were best described by the Langmuir isotherm model. The maximum monolayer adsorption capacity was 154.30 $\mathrm{mg} / \mathrm{g}$, evaluated using the Langmuir equation. The kinetic analysis revealed that the adsorption of $\mathrm{Cr}(\mathrm{VI}) \mathrm{was}$ fitted very well by the pseudo-second-order model during the whole adsorption process. The binding mechanism of chromium onto the AGJ surface was confirmed by Fourier transform infrared spectroscopy (FTIR) and X-ray photoelectron spectroscopy (XPS) analyses. All the results in this study illustrated that AGJ could be considered as an economically viable and effective adsorbent for treatment of aqueous solutions contaminated with $\mathrm{Cr}(\mathrm{VI})$.
\end{abstract}

Keywords: jute stalk, adsorption-coupled reduction, $\mathrm{Cr}(\mathrm{VI})$, kinetics, equilibrium

\section{INTRODUCTION}

Chromium, which is considered one of the top-priority toxic pollutants because of its teratogenic and carcinogenic effects in humans, exists in the environment mainly in two oxidation states, trivalent chromium $(\mathrm{Cr}(\mathrm{III}))$ and hexavalent chromium $(\mathrm{Cr}(\mathrm{VI})){ }^{1}$ Compared to $\mathrm{Cr}(\mathrm{III}), \mathrm{Cr}(\mathrm{VI})$ is more hazardous and toxic, owing to the highly soluble and mobile forms of hydrogen chromate $\left(\mathrm{HCrO}_{4}^{-}\right)$, dichromate $\left(\mathrm{Cr}_{2} \mathrm{O}_{7}{ }^{2-}\right)$ and chromate $\left(\mathrm{CrO}_{4}{ }^{2-}\right)$ ions in water streams. ${ }^{2}$ $\mathrm{Cr}(\mathrm{VI})$ is widely generated from various industrial processes, such as electroplating, pharmacy, metallurgy, textiles, battery and catalyst synthesis. ${ }^{3}$ The world health organization (WHO) recommends that the tolerance limit for $\mathrm{Cr}(\mathrm{VI})$ should be $0.05 \mathrm{mg} / \mathrm{L}$ for discharge into potable water, $0.1 \mathrm{mg} / \mathrm{L}$ into inland surface water, and $0.25 \mathrm{mg} / \mathrm{L}$ into industrial wastewater. ${ }^{4}$ Therefore, it is of critical importance to remove or reduce the concentration of $\mathrm{Cr}(\mathrm{VI})$ before its discharge into aquatic environments.

Several treatment techniques have been developed for removal of $\mathrm{Cr}(\mathrm{VI})$ from aqueous solutions, including reduction-precipitation, ${ }^{5}$ membrane separation (ultrafiltration, reverse osmosis and nanofiltration), ${ }^{6,7}$ electrolytic recovery, ${ }^{8}$ ion exchange/chelation, ${ }^{9}$ microbial remediation and adsorption. ${ }^{10,11}$ Of these methods, adsorption has been increasingly considered as an effective and versatile alternative for eliminating $\mathrm{Cr}(\mathrm{VI})$ from water and wastewaters. Activated carbon has been employed as a common adsorbent for the treatment of contaminants in aqueous solutions, but it is prohibitively expensive. $^{12}$ Therefore, low-cost adsorbents should be exploited for a simple and efficient adsorption in water and wastewater treatment. Recently, agricultural and industrial by-products, such as corn stalk, ${ }^{13}$ wheat straw, ${ }^{14}$ rice bran, ${ }^{15}$ sugar waste, ${ }^{16}$ coffee residues, ${ }^{17}$ and hydrolyzed lignocellulosic materials obtained from bioethanol production, ${ }^{18}$ have attracted the attention of scientists due to their naturally occurring, low-cost, abundant production and 
lignocellulose-rich content, as well as efficient adsorption to some extent. In addition, Sarkar et al. reported that water hyacinth shoot powder could be a potential adsorbent for removal of $\mathrm{Cr}$ and $\mathrm{Cu}$, with high adsorbent capacity of about 99\% $\mathrm{Cr}$ and $\mathrm{Cu}$ from a standard solution (SS), as well as from tannery effluent (TE). ${ }^{19}$

Jute is also an abundant agricultural waste, rich in cellulose and lignocelluloses, which has three hydroxyl groups at the anhydroglucose units of the cellulose backbone. Thus, it provides the possibility for application as adsorbent. ${ }^{20}$ However, the jute adsorbent lacks high adsorption capacity toward heavy metal contaminants in its native form. It was reported that the metal ion uptake reached values of only 4.23, 3.37 and 3.55 $\mathrm{mg} \mathrm{g}^{-1}$ for $\mathrm{Cu}(\mathrm{II}), \mathrm{Ni}(\mathrm{II})$ and $\mathrm{Zn}(\mathrm{II})$, respectively, by jute fibres. ${ }^{21}$ With the aim of enhancing the adsorption capacity, chemically modified cellulose absorbent has been synthesized. Hao et al. prepared a novel amino-functionalized cellulose adsorbent in an ionic liquid homogeneous system, which displayed a high removal efficiency for $\mathrm{Cr}(\mathrm{VI})$, with optimal $\mathrm{Cr}(\mathrm{VI})$ uptake of $32.5 \mathrm{mg} \mathrm{g}^{-1} .^{22}$ Du et al. have reported the preparation of a low-cost carboxyl modified jute fiber for removal of $\mathrm{Pb}(\mathrm{II}), \mathrm{Cd}(\mathrm{II})$, and $\mathrm{Cu}$ (II) from water, with remarkably high adsorption capacity (157.21, 88.98 and $43.98 \mathrm{mg} \mathrm{g}^{-1}$ for $\mathrm{Pb}(\mathrm{II}), \mathrm{Cd}(\mathrm{II})$, and $\mathrm{Cu}(\mathrm{II})$, respectively). ${ }^{23}$

The main objective of this work has been to investigate the potential use of an anionic adsorbent synthesized from jute stalks through amino-functionalization of natural cellulose in removing $\mathrm{Cr}(\mathrm{VI})$ anion species from water. The prepared anionic adsorbent from jute stalks was characterized by chemical analysis and the effects of important parameters, including adsorbent dosage and initial $\mathrm{pH}$ of the solution, were conducted using batch experiments. The potential application of functionalized jute stalks for adsorption of $\mathrm{Cr}(\mathrm{VI})$ from water was investigated under kinetic and equilibrium conditions. The mechanism of $\mathrm{Cr}(\mathrm{VI})$ adsorption onto the jute-based adsorbent was determined by several kinetic and isotherm adsorption models. The interaction between $\mathrm{Cr}(\mathrm{VI})$ and the adsorbent was eliminated by FTIR and XPS analyses.

\section{EXPERIMENTAL}

Preparation of amine grafted jute

The raw jute was obtained from the experimental field of the Institute of Bast Fiber Crops, Chinese Academy of Agricultural Sciences, China. It was washed with de-ionized (DI) water, dried in sunlight until all the moisture was evaporated. Then, the raw jute was smashed to pieces and sieved to the desired mesh size of $100 \sim 300 \mu \mathrm{m}$. For preparation of amine grafted jute (AGJ), a $250 \mathrm{~mL}$ three-neck round bottom flask was employed, and then two grams of raw jute powder, $10 \mathrm{~mL}$ of epichlorohydrin and $12 \mathrm{~mL}$ of $\mathrm{N}, \mathrm{N}$-dimethylformamide were mixed in it and stirred for $1 \mathrm{~h}$ at $100{ }^{\circ} \mathrm{C}$. After addition of $2 \mathrm{~mL}$ of diethylenetriamine drop by drop, the mixture was stirred for another $1 \mathrm{~h}$, followed by the addition of 10 $\mathrm{mL}$ of triehylamine and stirring for $3 \mathrm{~h}$. The primary product was washed with DI water, freeze-dried for 24 $\mathrm{h}$, and then sieved to an appropriate mesh size of $100 \sim 300 \mu \mathrm{m}$. Finally, the obtained samples were stored in desiccators as absorbents.

\section{Characterization of adsorbents}

The morphologies of raw jute and AGJ were observed by scanning electron microscopy (SEM) using a JSM-5600 LV microscope (JEO, Ltd., Japan). The BET surface area was determined by an ASAP 2020 Accelerated Surface Area and Porosimetry System (Micromeritics Instrument Corporation, USA). Infrared adsorption spectra were recorded on a Fourier transform infrared (FTIR) spectrometer (IRAffinity-1, Shimadzu) at room temperature, in the range from 400 to $4000 \mathrm{~cm}^{-1}$. The composition and binding energy information of AGJ and AGJ loaded with $\mathrm{Cr}(\mathrm{VI})$ were investigated by X-ray photoelectron spectroscopy (XPS), using a Thermo Scientific Escalab 250Xi spectrometer equipped with a monochromic $\mathrm{Mg} \mathrm{K} \alpha$ $\mathrm{X}$-ray source. Detailed spectra processing was performed by commercial Thermo Avantage software (v. 5.52, Thermo Scientific).

\section{Adsorption experiments}

All adsorption experiments were conducted in sealed $50 \mathrm{~mL}$ conical flasks that contained $20 \mathrm{mg}$ AGJ and $20 \mathrm{~mL} \mathrm{Cr}(\mathrm{VI})$ solution with appropriate concentrations. The flasks were placed on an incubator at $150 \mathrm{rpm}$ shaking speed at an appropriate temperature. After adsorption, samples were drawn out from the flasks and then filtered through a $0.45 \mu \mathrm{m}$ membrane filter. The residual concentration of $\mathrm{Cr}(\mathrm{VI})$ in the filtrate was analyzed using a UV-vis spectrophotometer (Shimadzu UV-2550, Japan). The pink complex formed from $\mathrm{Cr}(\mathrm{VI})$ and 1,5-diphenylcarazide was determined at the maximum adsorption wavelength of $540 \mathrm{~nm} .^{24}$ The amount adsorbed $\left(q_{e}, \mathrm{mg} / \mathrm{g}\right)$ was calculated as follows:

$q_{e}=\frac{\left(C_{0}-C_{e}\right) V}{m}$

where $C_{0}$ and $C_{e}$ are the initial and equilibrium 
concentrations of $\mathrm{Cr}(\mathrm{VI})(\mathrm{mg} / \mathrm{L}), V$ is the solution volume (L), and $m$ is the mass of adsorbent $(\mathrm{g})$.

In the dosage experiments, 5 80 $\mathrm{mg}$ dosages of AGJ were added into batches of $20 \mathrm{~mL}$ of $\mathrm{Cr}(\mathrm{VI})$ solution with the concentration of $100 \mathrm{mg} / \mathrm{L}$ under stirring conditions for $4 \mathrm{~h}$ at natural $\mathrm{pH}$. The effect of $\mathrm{pH}$ on the adsorption of AGJ was investigated by mixing $20 \mathrm{mg}$ of AGJ with $20 \mathrm{~mL}$ of $100 \mathrm{mg} / \mathrm{L} \mathrm{Cr}(\mathrm{VI})$ solution at different initial $\mathrm{pH}$ values of 2 9.The solution $\mathrm{pH}$ was adjusted with $0.5 \mathrm{M} \mathrm{NaOH}$ or $\mathrm{HCl}$ solution. To determine the minimum time required for reaching adsorption equilibrium, adsorption kinetics studies were carried out with various concentrations of $\mathrm{Cr}(\mathrm{VI}) \quad(50,100$ and $200 \mathrm{mg} / \mathrm{L})$ at $25{ }^{\circ} \mathrm{C}$. The concentrations of $\mathrm{Cr}(\mathrm{VI})$ were analyzed at given time intervals from $1 \mathrm{~min}$ to $4 \mathrm{~h}$. The adsorption isotherms of $\mathrm{Cr}(\mathrm{VI})$ on AGJ were obtained at $25^{\circ} \mathrm{C}, 35^{\circ} \mathrm{C}$ and $45{ }^{\circ} \mathrm{C}$, respectively, to evaluate the thermodynamic properties and the maximum adsorption. Typically, 20 $\mathrm{mL}$ of $\mathrm{Cr}(\mathrm{VI})$ with initial concentrations ranging from 10 to $500 \mathrm{mg} / \mathrm{L}$ were mixed with $20 \mathrm{mg}$ of $\mathrm{AGJ}$, and shaken for $4 \mathrm{~h}$ at constant temperature to attain equilibrium. After filtering separation, the $\mathrm{Cr}(\mathrm{VI})$ concentrations were measured.

\section{RESULTS AND DISCUSSION Characterization}

The morphologies of raw jute and AGJ were observed using SEM. As shown in Figure 1, the surface of AGJ was relatively smoother than that of raw jute, suggesting the order of cellulose in jute has been improved during the amination reaction. The BET measurement revealed that the specific surface areas of raw jute and AGJ were $75.84 \mathrm{~m}^{2} \mathrm{~g}^{-1}$ and $52.03 \mathrm{~m}^{2} \mathrm{~g}^{-1}$, respectively. The BET surface area of AGJ decreased after grafting with amine groups, which is consistent with the results of SEM analysis. These results are similar to those from a previous report. ${ }^{25}$

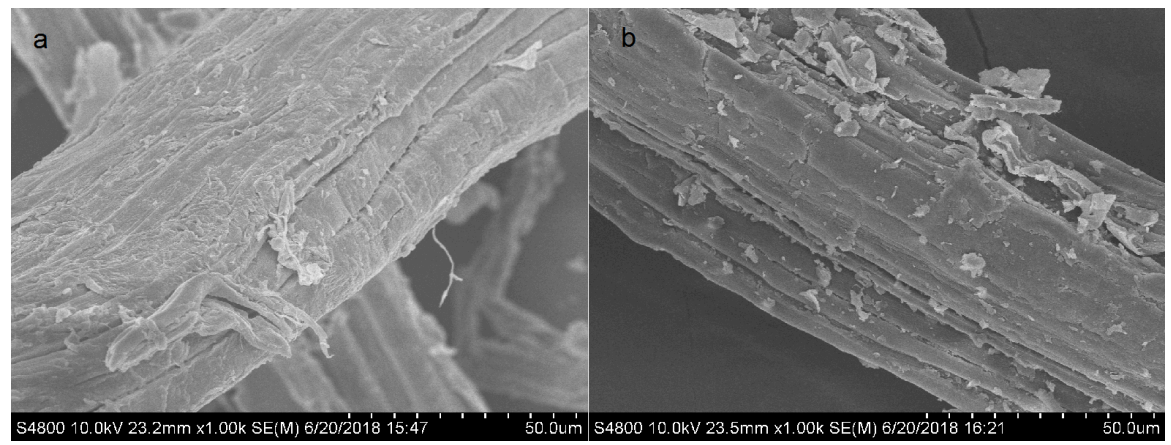

Figure 1: SEM images of raw jute (a) and AGJ (b)

FTIR spectral analysis is important to identify the characteristic functional groups, which are responsible for the adsorption of metal ions. ${ }^{26}$ The FTIR spectra of AGJ and Cr(VI) laden AGJ are displayed in Figure 2. It is apparent that there were some changes in the peak frequencies observed from the FTIR spectra. The spectrum of AGJ exhibits an absorption band at $3433 \mathrm{~cm}^{-1}$, which corresponds to the bonded -OH stretching vibration. After adsorption of $\mathrm{Cr}(\mathrm{VI})$, it shifted to $3419 \mathrm{~cm}^{-1}$ in the spectrum of $\mathrm{Cr}(\mathrm{VI})$ laden AGJ, partially owning to complexation of $\mathrm{Cr}(\mathrm{VI})$ with $-\mathrm{OH}$ groups. ${ }^{27}$ The appearance of a new peak at $892 \mathrm{~cm}^{-1}$ in the spectrum of $\mathrm{Cr}(\mathrm{VI})$ laden AGJ indicates the adsorption of $\mathrm{Cr}(\mathrm{VI})$ on AGJ. A similar phenomenon has been reported by Ren et $a l^{28}$ In the AGJ spectrum, the band at $1058 \mathrm{~cm}^{-1}$ corresponds to the C-O-C stretching vibration of the cellulose backbone. ${ }^{29}$ The broad band observed at 1641 and $1370 \mathrm{~cm}^{-1}$ could be assigned to the carboxyl and amine groups. ${ }^{30}$ After $\mathrm{Cr}(\mathrm{VI})$ binding, the characteristic peaks at 1641 and 1370 $\mathrm{cm}^{-1}$ shifted to 1646 and $1372 \mathrm{~cm}^{-1}$, respectively, indicating that amino and carboxyl groups contributed to the adsorption of $\mathrm{Cr}(\mathrm{VI})$. These results suggest that the adsorption of $\mathrm{Cr}(\mathrm{VI})$ onto AGJ could be ascribed to the complex interactions between $\mathrm{Cr}(\mathrm{VI})$ and AGJ, including electrostatic attraction, complexation, as well as ion exchange.

\section{Cr(VI) adsorption tests Effect of adsorbent dose on $\mathrm{Cr}(\mathrm{VI})$ adsorption}

The effect of AGJ dosage on $\mathrm{Cr}(\mathrm{VI})$ adsorption is shown in Figure 3. It can be noted that the uptake of $\mathrm{Cr}(\mathrm{VI})$ increased rapidly with the increasing dosage of AGJ adsorbent from 0.25 to 


\section{CANHUI DENG et al.}

$1.5 \mathrm{~g} / \mathrm{L}$. In this period, more $\mathrm{Cr}(\mathrm{VI})$ ions were removed, which could be ascribed to higher surface area and more active sites for $\mathrm{Cr}(\mathrm{VI})$ adsorption provided by increasing the AGJ dosage. The removal efficiency of $\mathrm{Cr}(\mathrm{VI})$ was maintained high (95 100\%) as the dosage of AGJ was increased from 1.5 to $4.0 \mathrm{~g} / \mathrm{L}$. However, the adsorption capacity $\left(q_{e}\right)$ of $\mathrm{Cr}(\mathrm{VI})$ by the AGJ adsorbent decreased from 116.3 to $27.7 \mathrm{mg} / \mathrm{g}$, while increasing the AGJ dosage from 0.25 to 4.0 $\mathrm{g} / \mathrm{L}$. Therefore, an optimum dosage of $1.0 \mathrm{~g} / \mathrm{L}$ was selected for subsequent adsorption experiments.

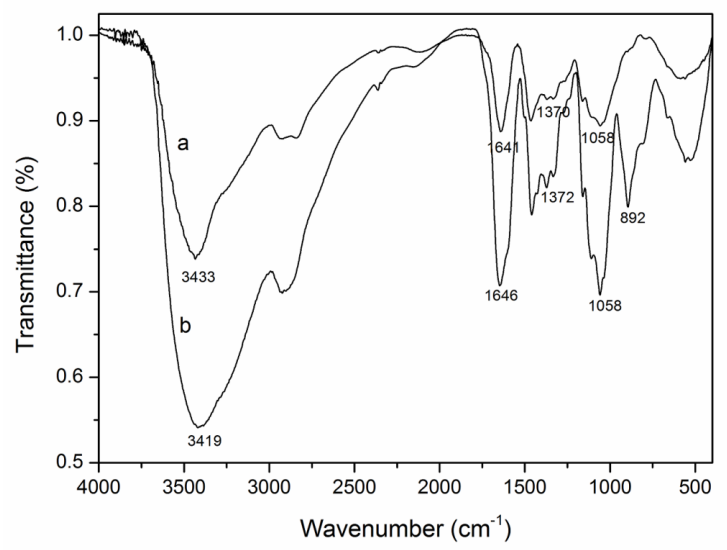

Figure 2: FTIR spectra of (a) AGJ and (b) Cr laden AGJ

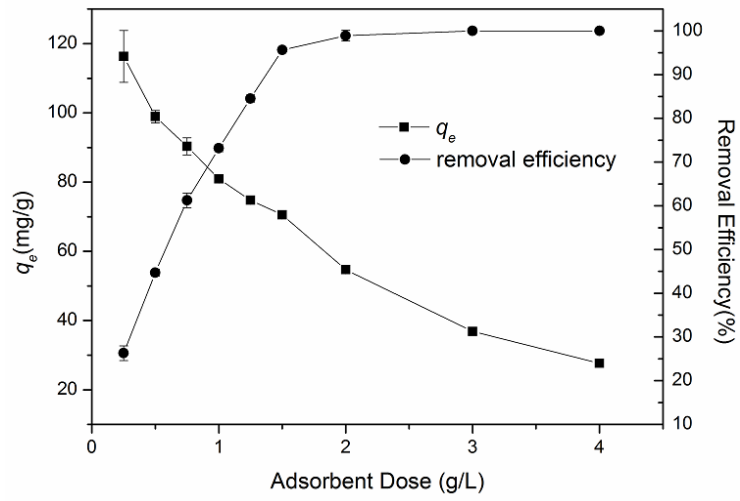

Figure 3: Effect of AGJ dosage on Cr(VI) adsorption (20 $\mathrm{mL}$ of $100 \mathrm{mg} / \mathrm{L} \mathrm{Cr}(\mathrm{VI})$ solution used with 0.25 to 4.0 $\mathrm{g} / \mathrm{L}$ of $\mathrm{AGJ}$ for $4 \mathrm{~h}$ )

\section{Effect of pH on Cr(VI) adsorption}

The $\mathrm{pH}$ is one of the most important factors for metal adsorption onto adsorbents from aqueous solution. The adsorption of $\mathrm{Cr}(\mathrm{VI})$ onto AGJ as a function of $\mathrm{pH}$ is illustrated in Figure 4. It can be noted that the uptake of $\mathrm{Cr}(\mathrm{VI})$ decreased from $103.42 \mathrm{mg} / \mathrm{g}$ to $35.07 \mathrm{mg} / \mathrm{g}$ with increasing $\mathrm{pH}$ from 2.04 to 9.33. There are various forms of $\mathrm{Cr}(\mathrm{VI})$ in aqueous solution, such as $\mathrm{HCrO}_{4}^{-}, \mathrm{Cr}_{2} \mathrm{O}_{7}{ }^{2-}, \mathrm{CrO}_{4}{ }^{2-}$, etc. The chromate anions $\mathrm{HCrO}_{4}^{-}$and $\mathrm{Cr}_{2} \mathrm{O}_{7}{ }^{2-}$ are predominant between $\mathrm{pH} 2.0$ and 6.0, while $\mathrm{CrO}_{4}{ }^{2-}$ is predominant above $\mathrm{pH}$ 6.0. ${ }^{25}$ It suggests that one adsorption site from AGJ was required for the

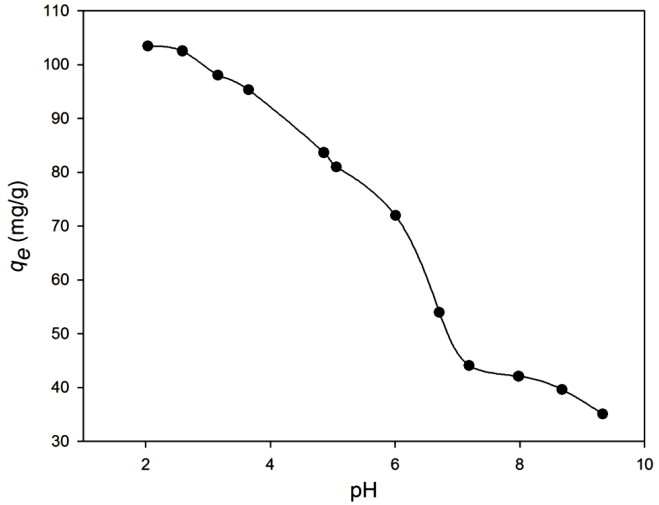

Figure 4: Adsorption performance of AGJ at different initial $\mathrm{pH}$ of $\mathrm{Cr}(\mathrm{VI})$ solution $(20 \mathrm{mg}$ AGJ used with $20 \mathrm{~mL}$ of $100 \mathrm{mg} / \mathrm{L} \mathrm{Cr}(\mathrm{VI})$ solution at different initial $\mathrm{pH}$ values of 2 9 for $4 \mathrm{~h}$ )

adsorption of dominant $\mathrm{HCrO}_{4}^{-}$at lower $\mathrm{pH}$, while two adsorption sites were necessary for the adsorption of divalent $\mathrm{Cr}_{2} \mathrm{O}_{7}{ }^{2-}$ or $\mathrm{CrO}_{4}{ }^{2-}$ at high $\mathrm{pH}^{31}{ }^{31}$ Therefore, there was a higher adsorption capacity of $\mathrm{Cr}(\mathrm{VI})$ ions by AGJ at lower $\mathrm{pH}$ than at relatively higher $\mathrm{pH}$.

In addition, at lower $\mathrm{pH}$, the protonation of the amino groups grafted onto AGJ was enhanced, and as a result, more negatively charged $\mathrm{Cr}(\mathrm{VI})$ ions were attracted by more positively charged hydronium ions $\left(\mathrm{H}^{+}\right)$on the surface of AGJ. In contrast, at higher $\mathrm{pH}$, the $\mathrm{OH}^{-}$anion was increased with the increasing $\mathrm{pH}$, which resulted in repulsion between the $\mathrm{OH}^{-}$and the negatively 
charged $\mathrm{Cr}(\mathrm{VI})$ ions, whilch led to a decreasing adsorption capacity for $\mathrm{Cr}(\mathrm{VI}){ }^{32}$

\section{Adsorption kinetics}

The adsorption kinetics of $\mathrm{Cr}(\mathrm{VI})$ by AGJ at different $\mathrm{Cr}(\mathrm{VI})$ concentration is shown in Figure 5. It is worth noting that the adsorption rate increased dramatically within the first $10 \mathrm{~min}$ and the adsorbed amount of $\mathrm{Cr}(\mathrm{VI})$ reached 48.56, 79.14 and $98.92 \mathrm{mg} / \mathrm{g}$, when the initial $\mathrm{Cr}(\mathrm{VI})$ concentration was 50, 100 and $200 \mathrm{mg} / \mathrm{g}$, respectively. The rapid uptake in the initial stage could be attributed to the high concentration gradient, which displayed a high driving force for migration of $\mathrm{Cr}(\mathrm{VI})$ from the solution onto the surface of AGJ. Subsequently, the adsorption rate was observed to be slow and an apparent equilibrium was achieved. The equilibrium time for adsorption of $\mathrm{Cr}(\mathrm{VI})$ onto the surface of AGJ was found to be around $60 \mathrm{~min}$ for different concentrations of $\mathrm{Cr}(\mathrm{VI})$.

In order to understand the mechanism involved in the adsorption process, the adsorption kinetics was examined. Numerous kinetic models provide an insight into the reaction order of adsorption based on the capacity of the adsorbent and the

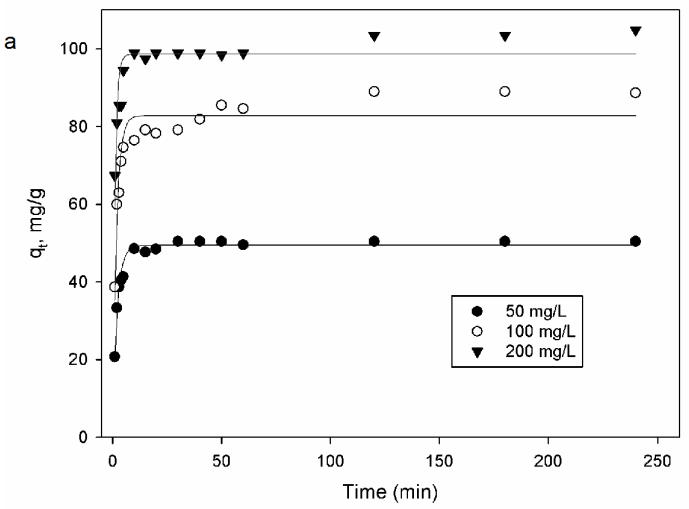

solution concentration. ${ }^{33}$ To evaluate the adsorption kinetics of $\mathrm{Cr}(\mathrm{VI})$ onto AGJ, several models have been employed: the Lagergren pseudo-first-order model and pseudo-second-order model and the Elovich equation model.

The pseudo-first-order model and the pseudo-second-order model are described by Equation 2 and Equation 3, while the Elovich equation is presented in Equation 4:

$$
\begin{aligned}
& q_{t}=q_{e}\left(1-e^{-k_{1} t}\right) \\
& q_{t}=\frac{t}{\frac{1}{k_{2} q_{e}^{2}}+\frac{t}{q_{e}}} \\
& q_{t}=\frac{1}{\beta} \ln (\alpha \beta)+\frac{1}{\beta} \ln (t)
\end{aligned}
$$

where $q_{e}$ and $q_{t}(\mathrm{mg} / \mathrm{g})$ are adsorption capacity at equilibrium and time $t(\mathrm{~min})$, respectively; $k_{I}$ $\left(\mathrm{min}^{-1}\right)$, and $k_{2}\left(\mathrm{~g} \mathrm{mg}^{-1} \mathrm{~min}^{-1}\right)$ are the rate constant of pseudo-first-order, pseudo-second-order model and intra-particle diffusion model, respectively; Elovich kinetic constants, $\alpha\left(\mathrm{mg}(\mathrm{g} \mathrm{min})^{-1}\right)$ is the initial adsorption rate, and $\beta\left(\mathrm{g} \mathrm{mg}^{-1}\right)$ is the desorption constant.

Figure 5: Adsorption kinetic data of $\mathrm{Cr}(\mathrm{VI})$ at different concentration of 50, 100 and $200 \mathrm{mg} / \mathrm{L}$ onto AGJ, fitted by pseudo-first-order (a) and pseudo-second-order model (b)

All the corresponding kinetic parameters from the four models for different concentrations are presented in Table 1. It was observed that the pseudo-first-order model showed relatively small values of correlation coefficients $\left(R^{2}\right)$, indicating the limitations of the boundary layer in controlling the adsorption process. It is known that the pseudo-first-order kinetic model is generally applicable to the adsorption process at the initial stage, but does not fit well to the whole process in many cases. ${ }^{34}$ However, the $R^{2}$ values were close to 1 for all $\mathrm{Cr}(\mathrm{VI})$ concentrations, when the experimental data fitted the pseudo-second-order model, which suggested that the rate-controlling process of the adsorption could be chemical adsorption, involving valence 
forces by exchange or sharing electrons between the adsorbate and the adsorbent.

The Elovich equation was applied to describe the chemical reaction mechanism involving the rate-controlling process of adsorption. ${ }^{35}$ As can be seen from Table 1, the initial adsorption rate constant $\alpha$ increased with initial $\mathrm{Cr}(\mathrm{VI})$ concentration, owing to the higher driving force. The desorption constant $\beta$ should decrease with initial concentration because of less available surface for $\mathrm{Cr}(\mathrm{VI})$, which was not consistent with the result obtained in this research, indicating that the Elovich equation was not suitable for describing the adsorption kinetics of $\mathrm{Cr}(\mathrm{VI})$ onto AGJ.

\section{Adsorption isotherms}

The adsorption equilibrium of $\mathrm{Cr}(\mathrm{VI})$ onto AGJ was evaluated at different temperatures to assess the adsorption capacity of the latter. Three important isotherm models were employed in this research to analyze the batch experimental data: the Langmuir, Freundlich and Temkin isotherm models.

The Langmuir model is based on the monolayer kinetic equilibrium between adsorption and desorption, as follows: ${ }^{36}$

$q_{e}=\frac{q_{m} K_{L} C_{e}}{1+K_{L} C_{e}}$

The Freundlich model is an empirical multilayer adsorption isotherm for non-ideal adsorption onto heterogeneous surfaces, and it has the following form: ${ }^{37}$

$q_{e}=K_{F} C_{e}^{1 / n}$

The Temkin equation is:

$q_{e}=B \ln A+B \ln C_{e}$

where $q_{e}(\mathrm{mg} / \mathrm{g})$ and $C_{e}(\mathrm{mg} / \mathrm{L})$ are related to the equilibrium concentrations in the solid phase and fluid phase, respectively. In the Langmuir model, $q_{m}(\mathrm{mg} / \mathrm{g})$ is the maximum adsorption capacity of the monolayer, $K_{L}(\mathrm{~L} / \mathrm{mg})$ is the equilibrium constant. In the Freundlich model, $K_{F}$ $\left(\mathrm{mg} / \mathrm{g}(\mathrm{L} / \mathrm{mg})^{1 / n}\right)$ and $1 / n$ are related to the adsorption capacity and adsorption intensity, respectively. The parameter $1 / n$ must be between 0 and 1 . In the Temkin model, $A(\mathrm{mg} / \mathrm{L})$ is the equilibrium binding constant and $B$ is the Temkin constant related to the heat of adsorption.

All the constants and correlation coefficients obtained from the three isotherm models for $\mathrm{Cr}(\mathrm{VI})$ adsorption onto AGJ are summarized in
Table 2. The adsorption isotherm data of $\mathrm{Cr}(\mathrm{VI})$ at different temperatures fitted with the Langmuir model are shown in Figure 6. On the basis of the correlation coefficients $\left(R^{2}\right)$, the Langmuir model gave the highest $R^{2}$ values, which were greater than 0.96 at all the three temperatures tested, showing that the Langmuir model yields the best fit, among the isotherms examined here. This result indicates that a monomolecular layer was formed without any interactions between the adsorbed molecules in the adsorption process of $\mathrm{Cr}(\mathrm{VI})$. The value of $q_{\mathrm{m}}$, calculated from the Langmuir equation, increased with the increasing temperature, and reached $154.30 \mathrm{mg} / \mathrm{g}$ at $40{ }^{\circ} \mathrm{C}$, which confirmed that the adsorption process for $\mathrm{Cr}(\mathrm{VI})$ onto AGJ was an endothermic reaction.

For the Freundlich model, the value of $1 / n$ ranged between 0 and 1 at all temperatures, indicating favorable adsorption of $\mathrm{Cr}(\mathrm{VI})$ onto AGJ. Similar results have been reported in the adsorption of $\mathrm{Cr}(\mathrm{VI})$ onto a new ion-exchanger derived from wheat straw. ${ }^{33}$ The Temkin constant $\mathrm{B}$ increased with the increase in the solution temperature, also suggesting the endothermic property of the $\mathrm{Cr}(\mathrm{VI})$ adsorption process. ${ }^{38}$

\section{Uptake mechanism}

XPS is one of the most useful tools for analyzing the adsorption interaction and the defining adsorption mechanisms. ${ }^{39}$ XPS spectra could be employed to determine particular elements and to identify the valence state of metals laden on AGJ. XPS analysis of AGJ before and after adsorption of $\mathrm{Cr}(\mathrm{VI})$ is depicted in Figure 7. As indicated in Figure 7a, the elemental composition of AGJ was determined and the peaks were successfully assigned to the corresponding carbon, oxygen, nitrogen and chromium atoms. Compared to AGJ, new peaks of $\mathrm{Cr} 2 \mathrm{p}$ appeared in the $\mathrm{Cr}$ laden AGJ, indicating the successful adsorption of $\mathrm{Cr}(\mathrm{VI})$ onto the surface of the AGJ composite.

As shown in Figure 7a, after AGJ adsorbed $\mathrm{Cr}(\mathrm{VI})$, two new peaks appeared at binding energies of $585.9 \mathrm{eV}$ and $576.2 \mathrm{eV}$. As may be noticed in the magnified Figure $7 \mathrm{~b}$, the peaks at $585.9 \mathrm{eV}$ and $576.2 \mathrm{eV}$ were characteristic peaks of $\mathrm{Cr} 2 \mathrm{p}_{1 / 2}$ and $\mathrm{Cr} 2 \mathrm{p}_{3 / 2}$, which suggests the presence of $\mathrm{Cr}(\mathrm{III})$ in AGJ after adsorption. ${ }^{40}$ 
Table 1

Kinetic data and correlation coefficient $\mathrm{R}^{2}$ obtained from kinetic models

\begin{tabular}{|c|c|c|c|c|c|c|c|c|c|}
\hline \multirow{2}{*}{$\begin{array}{c}C_{0} \\
\left(\mathrm{mg} \mathrm{L}^{-1}\right)\end{array}$} & \multicolumn{2}{|c|}{ Pseudo-first order } & \multicolumn{2}{|c|}{ Pseudo-second order } & \multicolumn{3}{|c|}{ Elovich } & \multicolumn{2}{|c|}{ Intra-particle diffusion } \\
\hline & $K_{l}\left(\min ^{-1}\right)$ & $R^{2}$ & $K_{2}\left(\mathrm{~g}(\mathrm{mg} \min )^{-1}\right)$ & $R^{2}$ & $\alpha\left(\mathrm{mg}(\mathrm{g} \min )^{-1}\right)$ & $\beta\left(\mathrm{g} \mathrm{mg}^{-1}\right)$ & $R^{2}$ & $k_{p}\left(\operatorname{mg}(\mathrm{g} \min )^{-1}\right)$ & $R^{2}$ \\
\hline 50 & 0.1656 & 0.8879 & 0.0236 & 0.9999 & $8.63 \times 10^{1}$ & 0.0856 & 0.9532 & 11.6965 & 0.8521 \\
\hline 100 & 0.2126 & 0.8267 & 0.0110 & 0.9992 & $1.74 \times 10^{2}$ & 0.0535 & 0.9299 & 18.9846 & 0.8097 \\
\hline 200 & 0.4180 & 0.8702 & 0.0073 & 0.9991 & $2.25 \times 10^{3}$ & 0.0736 & 0.9498 & 13.7857 & 0.8733 \\
\hline
\end{tabular}

Table 2

Isotherm parameters obtained for $\mathrm{Cr}(\mathrm{VI})$ adsorption by AGJ

\begin{tabular}{lcccc}
\hline \multirow{2}{*}{ Isotherm models } & \multirow{2}{*}{ Parameters } & \multicolumn{3}{c}{ Temperature } \\
\cline { 3 - 5 } & & 137.53 & $3{ }^{\circ} \mathrm{C}$ & $45^{\circ} \mathrm{C}$ \\
\hline \multirow{3}{*}{ Langmuir } & $q_{m}(\mathrm{mg} / \mathrm{g})$ & 0.0116 & 0.0098 & 0.0096 \\
& $K_{L}(\mathrm{~L} / \mathrm{mg})$ & 0.9823 & 0.9657 & 0.9767 \\
\hline \multirow{3}{*}{ Freundlich } & $R^{2}$ & 10.6883 & 9.3307 & 9.5478 \\
& $K_{F}\left(\mathrm{mg} / \mathrm{g}(\mathrm{L} / \mathrm{mg})^{1 / n}\right)$ & 0.4013 & 0.4314 & 0.4315 \\
& $1 / n$ & 0.9011 & 0.9134 & 0.9206 \\
\multirow{3}{*}{ Temkin } & $R^{2}$ & 0.1092 & 0.1024 & 0.1009 \\
& $A(\mathrm{mg} / \mathrm{L})$ & 30.5584 & 32.3793 & 33.1076 \\
& $B$ & 0.9806 & 0.9593 & 0.9689 \\
\hline
\end{tabular}




\section{CANHUI DENG et al.}

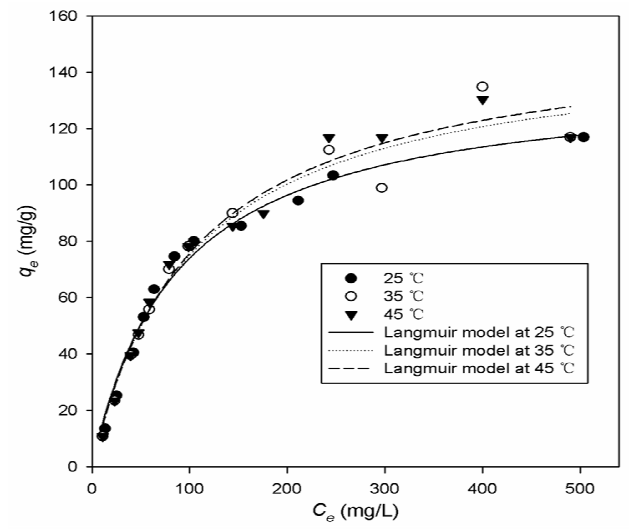

Figure 6: Adsorption isotherm of $\mathrm{Cr}(\mathrm{VI})$ at different temperature of 25,35 and $40{ }^{\circ} \mathrm{C}$ onto AGJ, fitted by Langmuir model
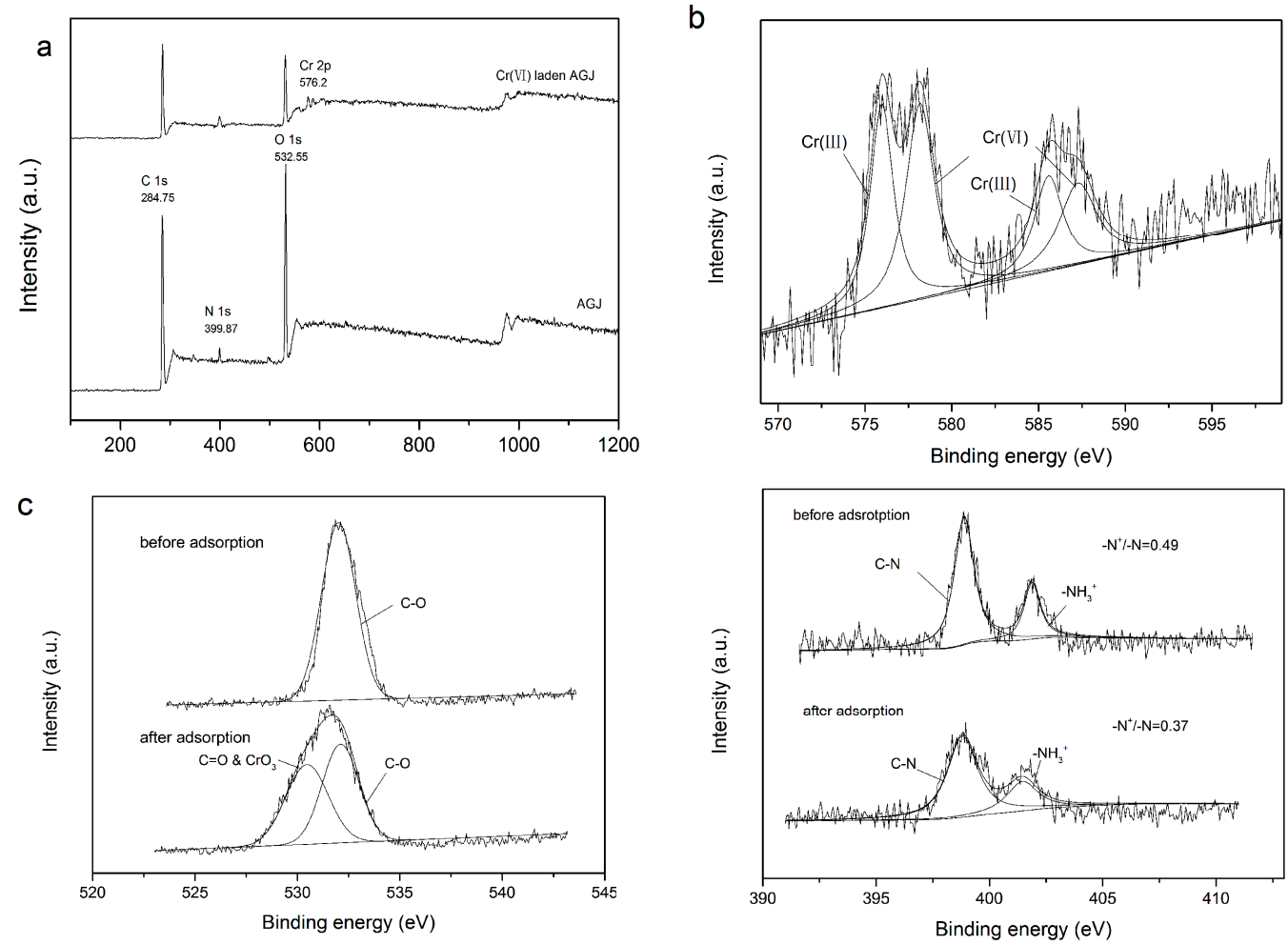

Figure 7: Wide scan XPS spectra of AGJ and Cr laden AGJ (a); Cr 2p on the AGJ surface after adsorption (b); $\mathrm{O} 1 \mathrm{~s}$ (c) and $\mathrm{N} 1 \mathrm{~s}$ (d) on the AGJ surface before and after adsorption

The peak of $\mathrm{Cr} 2 \mathrm{p}_{3 / 2}$ at the binding energy of $576.2 \mathrm{eV}$ could be fitted into two peaks at 576.0 and $578.1 \mathrm{eV}$, which was attributed to $\mathrm{Cr}(\mathrm{III})-\mathrm{OH}$ and $\mathrm{Cr}(\mathrm{VI})-\mathrm{O}$. The peak of $\mathrm{Cr} 2 \mathrm{p}_{1 / 2}$ at the binding energy of $585.9 \mathrm{eV}$ could be also fitted into two peaks at 585.6 and $587.3 \mathrm{eV}$, which was assigned to $\mathrm{Cr}(\mathrm{III})-\mathrm{OH}$ and $\mathrm{Cr}(\mathrm{VI})-\mathrm{O}$ in $\mathrm{Cr}_{2} \mathrm{O}_{7}^{2-}$ or $\mathrm{HCrO}_{4}^{-}$, respectively. These results indicated that a part of the laden $\mathrm{Cr}(\mathrm{VI})$ on the AGJ surface was reduced to the less toxic $\mathrm{Cr}(\mathrm{III})$, and AGJ also has an adsorption capacity for $\mathrm{Cr}(\mathrm{III}) .^{41}$

To further study the uptake mechanism of $\mathrm{Cr}(\mathrm{VI})$ by AGJ, the chemical status of $\mathrm{O} 1 \mathrm{~s}$ and $\mathrm{N}$ $1 \mathrm{~s}$ species on the adsorbent surface before and after $\mathrm{Cr}(\mathrm{VI})$ adsorption was also explored. As shown in Figure 7c, the band at $532.3 \mathrm{eV}$ corresponding to the peak of $\mathrm{C}-\mathrm{O}$ was lowered to a certain extent and some new peaks of $\mathrm{C}=\mathrm{O}$, $\mathrm{CrO}_{3}$ and $\mathrm{Cr}(\mathrm{OH})_{3}$ appeared after the adsorption of $\mathrm{Cr}(\mathrm{VI})$. These results suggested that chromium 
might bind to ligands containing oxygen, such as hydroxyl, carboxyl or phenolic groups, present on the surface of AGJ. In addition, the peak of $\mathrm{C}=\mathrm{O}$ increased obviously, which was due to the oxidation of the -OH group, implying that the hydroxyl groups were the electron donor during the process of $\mathrm{Cr}(\mathrm{VI})$ reduction to $\mathrm{Cr}(\mathrm{III})$. Also, the high resolution spectra of $\mathrm{N} \mathrm{1s}$ from AGJ before and after $\mathrm{Cr}(\mathrm{VI})$ adsorption are showed in Figure $7 \mathrm{~d}$. It can be noted that there are two obvious peaks in the spectrum of $\mathrm{N} 1 \mathrm{~s}$ from AGJ (see Fig. 3b) at binding energies of 398.8 and $401.7 \mathrm{eV}$, which were attributed to $\mathrm{N}$ atoms bonded with $\mathrm{C}$ atoms $(\mathrm{C}-\mathrm{N})$ and to $-\mathrm{NH}_{3}{ }^{+}$, respectively. ${ }^{28}$ The spectrum of $\mathrm{N} 1 \mathrm{~s}$ also illustrates the smaller contribution of positively charged $\mathrm{N}\left(-\mathrm{N}^{+}\right)$and the relatively larger contribution of neutral $\mathrm{N}(-\mathrm{N})$, and the ratio of $-\mathrm{N}^{+} /-\mathrm{N}$ was 0.49 for AGJ. However, after the adsorption of $\mathrm{Cr}(\mathrm{VI})$, the ratio of $-\mathrm{N}^{+} /-\mathrm{N}$ decreased to 0.37 (see Fig. 7d). This result indicates that the uptake of $\mathrm{Cr}(\mathrm{VI})$ by AGJ can be attributed to electrostatic attraction through the tertiary amine group.

The overall findings suggest that the adsorption of $\mathrm{Cr}(\mathrm{VI})$ on AGJ was not a simple, single process. The predominant mechanism might be chemisorption via amine, hydroxyl and/or the additional chemical functional groups of AGJ. Moreover, some other kinds of interactions, such as ion exchange, chemical bonding, hydrogen bonding and physical adsorption, also might be involved.

\section{CONCLUSION}

In this work, the adsorption performance of low-cost amino grafted jute stalks was investigated for the removal of $\mathrm{Cr}(\mathrm{VI})$ from aqueous solution. The results showed that the adsorption of $\mathrm{Cr}(\mathrm{VI})$ onto AGJ increased with increasing adsorbent dosage, but decreased with increasing initial solution $\mathrm{pH}$. The kinetic data were perfectly described by the pseudo-second-order model, indicating the occurrence of a chemical adsorption process. The equilibrium adsorption data at different temperatures fitted best to the Langmuir isotherms. The maximum adsorption capacity of AGJ for $\mathrm{Cr}(\mathrm{VI})$ was found to be $154.30 \mathrm{mg} / \mathrm{g}$. The nature of possible interactions between the adsorbent and the metal ion was examined by FTIR spectroscopy. It revealed the involvement of
$-\mathrm{OH},-\mathrm{NH}_{2}$ and $-\mathrm{COOH}$ groups in chromium binding onto the AGJ surface. Also, the results from XPS analysis revealed that a part of the adsorbed $\mathrm{Cr}(\mathrm{VI})$ onto the AGJ surface was reduced to less toxic $\mathrm{Cr}(\mathrm{III})$, and the reduced $\mathrm{Cr}$ (III) was then adsorbed onto the surface of AGJ. Besides that, as the adsorbent was developed from a low-cost lignocellulose-rich agricultural waste, it could be burned after $\mathrm{Cr}(\mathrm{VI})$ adsorption, without further regeneration, which would help reduce the cost of waste disposal. Therefore, it can be concluded that AGJ could serve as a potential adsorbent for chromium removal from aqueous solutions.

ACKNOWLEDGMENTS: The authors are grateful for the financial support from National Natural Science Foundation of China (31601351), the Hunan Natural Science Foundation (2017JJ3349 and 2017JJ3350), the Science and Technology Innovation Project of Chinese Academy of Agricultural Sciences (CAAS-ASTIP-2017-IBFC01 and CAAS-XTCX2016016-2), National Hemp Industry Technical System (CARS-16-E01), the Germplasm Resources Protection Project (2016NWB044) and Central Public-Interest Scientific Institution Basal Research Fund (1610242019003).

\section{REFERENCES}

1 G. Bayramoglu and M. Y. Arica, Chem. Eng. J., 139, 20 (2008), https://doi.org/10.1016/j.cej.2007.07.068

2 S. H. Chen, Q. Y. Yue, B. Y. Gao, Q. Li, X. Xu et al., Bioresour. Technol., 113, 114 (2012), https://doi.org/10.1016/j.biortech.2011.11.110

3 W. F. Liu, J. Zhang, C. L. Zhang and L. Ren, Chem. Eng. J., 189, $295 \quad$ (2012), https://doi.org/10.1016/j.cej.2012.02.082

4 Y. A. Aydin and N. D. Aksoy, Chem. Eng. J., 151, 188 (2009), https://doi.org/10.1016/j.cej.2009.02.010

5 V. K. Gupta, A. Rastogi and A. Nayak, J. Colloid. $\begin{array}{llll}\text { Interf. } & \text { Sci., } & \mathbf{3 4 2}, & 135\end{array}$ https://doi.org/10.1016/j.jcis.2009.09.065

6 J. Yoon, G. Amy, J. Chung, J. Sohn and Y. Yoon, Chemosphere, 77, $228 \quad$ (2009), https://doi.org/10.1016/j.chemosphere.2009.07.028

7 H. Ozaki, K. Sharma and W. Saktaywin, Desalination, 144, $287 \quad$ (2002), https://doi.org/10.1016/S0011-9164(02)00329-6

8 B. Mukhopadhyay, J. Sundquist and R. J. Schmitz, J. Environ. Manage., 82, $66 \quad$ (2007), https://doi.org/10.1016/j.jenvman.2005.12.005

9 E. Pehlivan and S. Cetin, J. Hazard. Mater., 163, 
448

https://doi.org/10.1016/j.jhazmat.2008.06.115

(2009),

10 Y. M. Qu, X. M. Zhang, J. Xu, W. J. Zhang and Y.

Guo, Sep. Purif. Technol., 136, 10 (2014), https://doi.org/10.1016/j.seppur.2014.07.054

11 X. J. Hu, J. S. Wang, Y. G. Liu, X. Li, G. M. Zeng et al., J. Hazard. Mater., 185, 306 (2011), https://doi.org/10.1016/j.jhazmat.2010.09.034

12 M. Bansal, D. Singh and V. K. Garg, J. Hazard.

Mater., $\quad$ 171, 83 (2009), https://doi.org/10.1016/j.jhazmat.2009.05.124

13 L. C. Zheng, C. F. Zhu, Z. Dang, H. Zhang, X. Y. Yi et al., Carbohyd. Polym., 90, 1008 (2012), https://doi.org/10.1016/j.carbpol.2012.06.035

14 M. Gorgievski, D. Bozic, V. Stankovic, N. Strbac and S. Serbula, Ecol. Eng., 58, 113 (2013), https://doi.org/10.1016/j.ecoleng.2013.06.025

15 Y. N. Chen, L. C. Ding and J. X. Nie, Desalin. Water Treat., 44, $168 \quad$ (2012), https://doi.org/10.1080/19443994.2012.691694

16 I. Anastopoulos, A. Bhatnagar, B. H. Hameed, Y. S. Ok and M. Omirou, J. Mol. Liq., 240, 179 (2017), https://doi.org/10.1016/j.molliq.2017.05.063

17 I. Anastopoulos, M. Karamesouti, A. C. Mitropoulos and G. Z. Kyzas, J. Mol. Liq., 229, 555 (2017), https://doi.org/ 10.1016/j.molliq.2016.12.096

18 P. S. Vassileva, A. K. Detcheva, T. H. R. Radoykova, I. A. Avramova, K. I. Aleksieva et al., Cellulose Chem. Technol., 52, 633 (2018), http://www.cellulosechemtechnol.ro/pdf/CCT7-8(2018 )/p.633-643.pdf

19 M. Sarkar, A. K. M. L. Rahman and N. C. Bhoumik, Water Resour. Ind., 17, 1 (2017), https://doi.org/ 10.1016/j.wri.2016.12.003

20 A. Roy, B. Adhikari and S. B. Majumder, Ind. Eng.

Chem. Res., 52, $6502 \quad$ (2013), https://doi.org/10.1021/ie400236s

21 S. R. Shukla and R. S. Pai, Bioresour. Technol., 96, 1430

(2005),

https://doi.org/10.1016/j.biortech.2004.12.010

22 Y. Hao, Z. P. Cui, H. Yang, G. B. Guo, J. Y. Liu et al., Cellulose Chem. Technol., 52, 485 (2018), http://www.cellulosechemtechnol.ro/pdf/CCT5-6(2018 )/p.485-494.pdf

${ }_{23}$ Z. L. Du, T. Zheng, P. Wang, L. L. Hao and Y. X. Wang, Bioresour. Technol., 201, 41 (2016), https://doi.org/10.1016/j.biortech.2015.11.009

24 M. Zheng, Y. Ahn, Y. Yoon, W. K. Park, Y. Jung et al., Sep. Sci. Technol., 51, 2958 (2016), https://doi.org/10.1080/01496395.2016.1231693

25 S. H. Chen, Q. Y. Yue, B. Y. Gao, Q. Li and X. Xu, Chem. Eng. J., 168, $909 \quad$ (2011), https://doi.org/10.1016/j.cej.2011.01.063

26 X. Y. Guo, S. Z. Zhang and X. Q. Shan, J. Hazard. Mater., $\quad 151, \quad 134 \quad$ (2008), https://doi.org/10.1016/j.jhazmat.2007.05.065
27 K. K. Singh, M. Talat and S. H. Hasan, Bioresour. Technol., 97, $2124 \quad$ (2006), https://doi.org/10.1016/j.biortech.2005.09.016

${ }^{28}$ Z. F. Ren, X. Xu, X. Wang, B. Y. Gao, Q. Y. Yue et al., J. Colloid. Interf. Sci., 468, 313 (2016), https://doi.org/10.1016/j.jcis.2016.01.079

${ }^{29}$ L. L. Hao, T. Zheng, J. P. Jiang, Q. Hu, X. L. Li et al., $\quad R S C \quad A d v$., $\quad$ 5, $10723 \quad$ (2015), https://doi.org/10.1039/c4ra11901k

30 L. V. A. Gurgel, J. C. P. de Melo, J. C. de Lena and L. F. Gil, Bioresour. Technol., 100, 3214 (2009), https://doi.org/10.1016/j.biortech.2009.01.068

31 A. M. Yusof and N. A. N. N. Malek, J. Hazard. Mater., $\quad$ 162, $1019 \quad$ (2009), https://doi.org/10.1016/j.jhazmat.2008.05.134

32 Q. Q. Zhong, Q. Y. Yue, B. Y. Gao, Q. Li and X. Xu, Chem. Eng. J., 229, $90 \quad$ (2013), https://doi.org/10.1016/j.cej.2013.05.083

33 S. H. Chen, Q. Y. Yue, B. Y. Gao and X. Xu, J. Colloid. Interf. Sci., 349, $256 \quad$ (2010), https://doi.org/10.1016/j.jcis.2010.05.057

34 M. W. Wan, C. C. Kan, B. D. Rogel and M. L. P. Dalida, Carbohyd. Polym., 80, 891 (2010), https://doi.org/10.1016/j.carbpol.2009.12.048

35 M. Y. Chang and R. S. Juang, Colloid. Surface. A, 269, 35

(2005),

https://doi.org/10.1016/j.colsurfa.2005.06.064

36 N. Tolazzi, E. Steffani, E. Barbosa-Coutinho, J. B. S. Junior, J. C. Pinto et al., Chem. Eng. Res. Des., 138, 144

(2018),

https://doi.org/10.1016/j.cherd.2018.08.027

37 G. O. Cassol, R. Gallon, M. Schwaab, E. Barbosa-Coutinho, J. B. Severo et al., Adsorpt. Sci. Technol., $\quad 32, \quad 257 \quad$ (2014), https://doi.org/10.1260/0263-6174.32.4.257

38 C. Y. Kuo, C. H. Wu and J. Y. Wu, J. Colloid. Interf. Sci., $\quad 327, \quad 308 \quad$ (2008), https://doi.org/10.1016/j.jcis.2008.08.038

39 C. H. Deng, J. L. Gong, G. M. Zeng, Y. Jiang, C. Zhang et al., Chem. Eng. J., 284, 41 (2016), https://doi.org/10.1016/j.cej.2015.08.106

40 N. Daneshvar, D. Salari and S. Aber, J. Hazard. Mater., $\quad 94, \quad 49$ (2002), https://doi.org/10.1016/S0304-3894(02)00054-7

41 N. Shevchenko, V. Zaitsev and A. Walcarius, Environ. Sci. Technol., 42, 6922 (2008), https://doi.org/ 10.1021/es800677b 